\title{
Pre-harvest application of fungicides influences the post-harvest quality of cauliflower (Brassica oleracea var. botrytis L.)
}

\author{
Gean C. Monteiro ${ }^{1}$, Mônica B. da Silva ${ }^{2}$, Luan F. O. S. Rodrigues ${ }^{1}$, Hector A. Gomez-Gomez ${ }^{1}$, Cristine Vanz \\ Borges $^{1}$, Igor O. Minatel ${ }^{2}$, Giuseppina P. P. Lima ${ }^{2 *}$
}

\author{
${ }^{1}$ Department of Horticulture, School of Agriculture, Sao Paulo State University, Botucatu, Sao Paulo, Brazil \\ ${ }^{2}$ Department of Chemistry and Biochemistry, Institute of Biosciences, Sao Paulo State University, Botucatu, Sao \\ Paulo, Brazil
}

\section{*Corresponding author: finalima@gmail.com}

\begin{abstract}
Two cauliflower cultivars (cv.) (Flamenco and Verona) were treated with fungicides (boscalid (Cantus $\left.\left.{ }^{\circ}\right)\right)\left(0.3 \mathrm{~g} \mathrm{~L}^{-1}\right)$, pyraclostrobin + fluxapyroxad (Orkestra $\left.{ }^{\circ} \mathrm{SC}\right)\left(0.3 \mathrm{~mL} \mathrm{~L}^{-1}\right)$, metiram + pyraclostrobin (Cabrio $\left.{ }^{\circ} \mathrm{Top}\right)\left(3.0 \mathrm{~g} \mathrm{~L}^{-1}\right)$ and metiram + pyraclostrobin + boscalid $\left(\right.$ Cantus $^{\circ}+$ Cabrio $\left.^{\circ} \mathrm{Top}\right)$ in order to evaluate their chemical composition and their influence on post-harvest quality. The fungicides were applied during the seedling stage as well as 30 days before harvest. Freshly harvested inflorescences were analyzed at 3-day intervals for up to 12 days in storage $\left(10 \pm 2{ }^{\circ} \mathrm{C}\right.$ and $\left.92 \pm 2 \% \mathrm{RH}\right)$ to verify the polyamine content, peroxidase and polyphenoloxidase activities and physicochemical attributes. All fungicides induced changes in polyamine metabolic pathways, resulting in increased levels of spermidine and spermine. These compounds may be related to the reduced activity of polyphenoloxidase and peroxidase and to cauliflower senescence. Pre-harvest application of metiram + pyraclostrobin + boscalid to $\mathrm{cv}$. Flamenco and of fluxapyroxad + pyraclostrobin to $\mathrm{cv}$. Verona were found to be the most efficient treatments for improving the commercial quality of cauliflower. No levels of the fungicides applied during the cultivation were detected in the post-harvest. The fungicides applied to the pre-harvest effectively prolong the storage time and visual quality of cauliflowers cv. Flamenco and cv. Verona.
\end{abstract}

Keywords: boscalid; enzymatic activity; metiram; polyamines; strobilurin; visual quality.

Abbreviation: B_boscalid; C_control; DAO_diamine oxidase; DPH_days of post-harvest; $F+P_{-}$fluxapyroxad + pyraclostrobin; FW_fresh weight; His_histamine; $M+P_{-}$metiram + pyraclostrobin; $M+P+B_{-}$metiram + pyraclostrobin + boscalid; PAO_polyamines oxidases; PAs_polyamines; POD_peroxidases; PPO_polyphenoloxidase; Put_putrescine; ROS_reactive oxygen species; TA_titratable acidity; Spd_spermidine; Spm_spermine; SS_soluble solids; WL_weight loss.

\section{Introduction}

Plants exposed to stress (biotic or abiotic) may exhibit imbalances between the production and the scavenging of reactive oxygen species (ROS). In order to decrease the ROS stress-induced, some molecules (antioxidants enzymatic and non-enzymatic) are produced as a mechanism of protection against adversities and contribute positively in the plant development, as well as, improving the post-harvest quality (Domínguez et al., 2012; Moschou et al., 2012). On the other hand, the agrochemical industry has produced molecules to induce plant resistance against pathogens as a form of protection during the development and consequently in the post-harvest. Modifications in plant metabolism result in direct production or blockage of metabolites with antioxidant action.

Polyamines can act as scavenging ROS, besides being related to the protein synthesis, DNA replication, morphogenesis (Sidana et al., 2015; Lima et al., 2017), growth, cell proliferation, differentiation, programmed cell death (Szepesi et al., 2011), xylem development, senescence
(Moschou et al., 2012), ionic balance, lignification and cellwall hardening (Amri and Shahsavar, 2010). Polyamines can also act as pro-oxidants, producing $\mathrm{H}_{2} \mathrm{O}_{2}$ by the action of oxidases (diamine oxidase, DAO, EC 1.4.3.6 and polyamine oxidases, PAO, EC 1.5.3.3). Hydrogen peroxide is considered a ROS, and it is related to programmed cell death (Moschou et al., 2012; Sidana et al., 2015). To reduce to possible oxidizing effects of hydrogen peroxide, enzymes such as peroxidase (POD; EC 1.11.1.7) can be induced by the increase in levels of peroxides. The polyphenoloxidase (PPO, EC 1.14.18.1) promotes the formation of quinones by oxidizing phenolic compounds (Huang et al., 2017), and can have its activity affected by the levels of oxidants. Both enzymes (POD and PPO) are liberated in tissues disrupted during the harvest and storage post-harvest due to some process, such as mechanical damage, injuries, microorganism presence, among others.

The impact of fungicides on systemic induced resistance and how this resistance may influence the post-harvest 
quality of vegetables - is not well understood. Thus, new studies are necessary to assess how the application of agrochemicals to fields influences the post-harvest quality of vegetables during storage, especially vegetables with a short commercialization period, such as cauliflower, which is commercialized mainly in natura. Cauliflower is cultivated in large quantities due to its good financial return, high productivity and nutritional value as well as it being one of the most consumed vegetables in many countries. In this study, we evaluated whether the pre-harvest application of some fungicides influences antioxidant metabolism, specifically the levels of polyamines and POD and PPO activity in a cauliflower post-harvest.

\section{Results and discussion}

\section{Residual fungicides}

After harvest, the presence of the fungicides applied during the pre-harvest was not observed by Thin Layer Chromatography (TLC) analysis. However, we observed that there was a change in cauliflower metabolism (cv. Flamenco and $\mathrm{cv}$. Verona), mainly in the polyamine content. Many studies have shown that some fungicides, such as boscalid, fluxapyroxad, pyraclostrobin and metiram applied in plants, have a half-life of 2.6 to 12.6 days. These compounds can dissipate rapidly after application and do not negatively affect human health. Therefore, they do not exceed toxicological reference values if the dosage and recommended period are followed (Chen and Zhang, 2010; Li et al., 2010, Li et al., 2013; You et al., 2012; Fu et al., 2016; He et al., 2016). Some studies have found that foods submitted to sanitization, bleaching, cooking, peeling or canning might contain reduced levels of pesticides (Jankowska et al., 2016; Łozowicka et al., 2016).

In our study, the last application of fungicide was 30 days before the harvest. As a result, there was time for the applied products to dissipate. Thus, the period of application of the product until the harvest and/or consumption was respected to prevent the product being contaminated by pesticide residues.

\section{Polyamine content in response to fungicides}

Both cv. Flamenco and cv. Verona showed a significant interaction with the polyamine levels as a result of the application of fungicides and storage $(0,3+3$ and $9+3$ days) (Tables 1 and 2). The putrescine levels were higher soon after the harvest of both cultivars, with the highest content occurring in inflorescences of cv. Verona treated with boscalid (Table 2). When these same cultivars did not receive any treatment, the putrescine levels at 12 days of storage $(9+3)$ were similar to the ones found soon after the harvest.

During the storage at $3+3$ and $9+3$ days, inflorescences of cv. Flamenco treated with fungicides showed higher spermidine content compared with the control. In contrast, cv. Verona treated with fungicide showed few variations in the spermidine level, except soon after the harvest (day 0) when boscalid was used. This result did not occur when we analyzed the spermine levels in cv. Verona. In cv. Flamenco, we did not detect histamine. In contrast, except in the control, the lowest content of this monoamine in cv. Verona was found after 12 days of storage when treated with fungicides. The values found for histamine in the cauliflowers did not exceed the level described as toxic (25 $\mathrm{mg} / \mathrm{meal} /$ person) (Latorre-Moratalla et al., 2017), and because consumption usually occurs after cooking, the levels would decrease even further due to the lixiviation of histamine in the cooking water.

At $9+3$ days of storage, cv. Flamenco treated with boscalid, pyraclostrobin and metiram showed high spermidine and spermine content (Table 1). This result was similar for cv. Verona treated with $M+P$. Higher polyamine levels were also found in tomato (Solanum lycopersicum, cv. Saladinha) treated with metiram + pyraclostrobin $\left(4.0 \mathrm{~g} \mathrm{~L}^{-1}\right)$ (Guimarães et al., 2014). These data may provide evidence that plants with high Spd and Spm levels could be less susceptible to the action of pathogens or abiotic stress and could thus improve their commercial durability. Both Spd and Spm have been described as one plant mechanism of protection against some stresses (Moschou et al., 2012; Guimarães et al., 2014; Zapata et al., 2017). The accumulation of Spd and Spm in response to the application of fungicides can be a determining factor for maintaining the post-harvest quality. These amines could play a role in maintaining the ionic balance and in stabilizing the membranes (Sidana et al., 2015) and could also be directly or indirectly related to cellwall lignification and hardening (Amri and Shahsavar, 2010), thus promoting a possible resistance to pathogens. The increased polyamine levels can induce programmed cell death (Walters, 2003) as a response to the pathogens' penetration. In necrotic areas of some infected tissues, an increased concentration of polyamines can be observed, especially in spermidine and putrescine as well as in enzymes that synthesize polyamines, such as ornithine decarboxylase and arginine decarboxylase (Torrigiani et al., 1997), which could serve as a form of pre-defense against certain types of stress.

In addition, polyamines can be oxidized via DAO and PAO, which generate $\mathrm{H}_{2} \mathrm{O}_{2}$, a signaling molecule related to programmed cell death. The amines' oxidase activity could be increased by the excess of polyamines during the regulation process. Some studies have demonstrated that induced resistance is directly associated with increased activity of amine oxidases (DAO and PAO) (Marini et al., 2001) and that, as $\mathrm{H}_{2} \mathrm{O}_{2}$ is generated during the oxidation, it might act as a free radical and impair the functions of both the plant and of the pathogen cells. Thus, an increase in the polyamine content in response to the application of fungicides can be beneficial as a form of protection, as was observed in this study.

Early senescence was observed in some plants (mainly in the control), with dark spots in the inflorescences (Fig 1), probably due to oxidative processes and fungal contamination. The use of fungicides was effective in maintaining the post-harvest quality of cauliflower, and the application of $\mathrm{M}+\mathrm{P}+\mathrm{B}$ extended the post-harvest visual quality for 12 days for $\mathrm{cv}$. Flamenco. On the other hand, $\mathrm{F}+$ $P$ was the most efficient treatment for $c v$. Verona, extending the longevity and visual quality, likely due to alterations in the polyamine levels. Polyamines may have contributed to this increase in longevity because they compete for the same common precursor of ethylene (Sadenosylmethionine) (Zapata et al., 2017). Lower levels of ethylene could be beneficial in increasing post-harvest life. 


\section{Enzymatic activity}

The fungicide treatment promoted a decrease of the POD and PPO activities in cv. Flamenco and cv. Verona (Table 3) compared to the control. The highest activity in cv. Flamenco, for both enzymes, occurred after three days of storage at room temperature (Table 3). In cv. Flamenco, the lowest activities were observed after the use of pyraclostrobin and metiram $(\mathrm{M}+\mathrm{P}$ or $\mathrm{M}+\mathrm{P}+\mathrm{B})$; however, the application of only boscalid did not induce the same responses. In contrast, cv. Verona without fungicide application (control) showed increased POD and PPO activities during storage. Lower activities of both enzymes were found in $\mathrm{cv}$. Verona inflorescences treated with $\mathrm{M}+\mathrm{P}+$ $B$ (Table 3). These results demonstrate that the use of the fungicides can affect the enzymatic activity in both cultivars. Some studies have found evidence that the alterations in oxidative enzymes are a response to the application of fungicides (Teisseire and Vernet, 2001). Generally, the increase in the activities of enzymes, such as POD, is related to a consequence of biotic or abiotic stress due to the formation of peroxides. Studies have shown that the application of fungicides can induce an increase in the enzymatic activities by generating an overproduction of ROS (Teisseire and Vernet, 2001). In our study, the combination of $M+P+B$ was efficient in avoid contamination by fungi; however, according to the enzymes analyzed, that combination did not promote enough stress to influence the post-harvest durability of the studied cauliflower cultivars.

In our study, the combination $\mathrm{M}+\mathrm{P}+\mathrm{B}$ was efficient in the prevention of fungi and, according to the enzymes analyses, did not promote enough stress to influence in the postharvest durability of the studied cauliflower cultivars.

We also analyzed the content of polyamines during the postharvest. Generally, these amines are oxidized and generate peroxides, thus promoting an increase in the peroxidase activity (Moschou et al., 2012). However, we verified that there was no decrease in the polyamine levels and that peroxidase activity was low during storage, which could indicate a maintaining the quality, influenced by the application of fungicides, mainly the combination of $\mathrm{M}+\mathrm{P}+$ B. According to the data, the application of fungicides contributed to increased resistance of the cauliflower inflorescences. The low enzymatic activity found in this study might mean that these plants present higher longevity and are less susceptible to deterioration after harvest.

\section{Physicochemical characteristics and weight loss}

Both cv. Flamenco and cv. Verona showed different behaviors with regard to weight loss and the physicochemical characteristics as a result of the fungicide applied (Tables 4, 5 and 6). There were no differences in the levels of soluble solids, titratable acidity (TA) and $\mathrm{pH}$ among the treatments for cv. Flamenco, which presented the lowest weight loss after treatment with $B$ and $F+P$. In contrast, the lowest weight loss for $\mathrm{cv}$. Verona occurred after the treatment with $M+P$ (Table 4). Fungicides were not efficient, however, in preventing weight loss in the postharvest for both studied cultivars. Weight loss can be attributed to the increase of metabolic activity in the inflorescences - mainly due to the temperature action during storage. Zhan et al. (2014) found weight loss from 1.4
$\%$ to $1.8 \%$ in cauliflower inflorescences stored at $7{ }^{\circ} \mathrm{C}$. Higher losses (from $8.31 \%$ to $11.66 \%$ ) were described by Brackmann et al. (2005) in cauliflowers at $0.5{ }^{\circ} \mathrm{C}$, while Olarte et al. (2009) verified that these vegetables stored at 4 ${ }^{\circ} \mathrm{C}$ showed weight losses from $1.8 \%$ to $10.1 \%$. At higher temperatures, as used in this experiment $\left(10{ }^{\circ} \mathrm{C}\right)$ or in environmental conditions (around $25{ }^{\circ} \mathrm{C}$ ) (simulated commercialization), higher water loss can occur by transpiration. In addition, temperatures above the recommended $10{ }^{\circ} \mathrm{C}$ can affect metabolic pathways, which are catalysed by enzymes, thus causing an early senescence. It is worth pointing out that the data were obtained from inflorescences, demonstrating that fungicides do not influence weight loss post-harvest.

The lowest SS contents in cv. Verona (Table 5) occurred soon after the harvest with the application of F + P. Inflorescences of cv. Verona, regardless of treatment, showed an SS increase during the simulated commercialization. This result is possibly related to the mass loss during storage, together with physiological alterations found in the treatments with the application of fungicides, as found in tomatoes treated with pyraclostrobin + boscalid (Ramos et al., 2013). However, the application of fungicides did not influence the SS content in cv. Flamenco, except at $3+3$ days.

Inflorescences of cv. Verona without fungicide treatment during the cultivation showed higher titratable acidity (TA) levels, except at 3 days in a cold chamber and $9+3$ days (simulated commercialization) (Table 5). Inflorescences cultivated under the application of $\mathrm{M}+\mathrm{P}$, showed lower $\mathrm{pH}$ soon after the harvest. During storage, there was a decrease of the $\mathrm{pH}$ regardless of the treatment used. However, inflorescences of cv. Flamenco showed no representative variations during storage, except for a slight increase in TA and a decrease in $\mathrm{pH}$ at $3+3$ days (Table 5). Other studies have not shown the influence of fungicides in the TA (Domínguez et al., 2012; Ramos et al., 2013). In tomato, the combination $\mathrm{P}+\mathrm{B}$ applied in the pre-harvest did not affect the TA in relation to the control (Domínguez et al., 2012).

As in other quality characteristics that were analyzed, few studies have shown the influence of these agrochemicals in relation to vitamin C in cauliflower. The levels of vitamin $C$ were higher soon after the harvest in both cv. Flamenco and cv. Verona (Table 6). Ramos et al. (2013) verified that the pre-harvest application of $\mathrm{P}+\mathrm{B}$ in tomato promoted an increase of $10.5 \%$ in the vitamin $C$ content. We verified this finding on the harvest day, with the highest vitamin $C$ content being found in $\mathrm{cv}$. Flamenco that had been treated with $\mathrm{M}+\mathrm{P}+\mathrm{B}$ (32.04\% higher than the control). However, at day 12 , the vitamin $C$ decrease was $67.52 \%$. In cv. Verona, the pre-harvest treatments influenced the vitamin $C$ levels only at 6 and 9 days of storage. In addition to showing the lowest vitamin C content, cv. Verona, when compared to $\mathrm{cv}$. Flamenco, presented the highest losses during the storage (around $81.73 \%$ ). For both studied cultivars, there was a decrease in the vitamin C during storage. After harvest, vegetables tend to begin senescence; consequently, they present a decrease in the content of some compounds, including the vitamin C. Many studies have attributed this vitamin $C$ decrease to degradation by oxidative enzymes (Zhan et al., 2014; Huang et al., 2017).

Plants' metabolism can be redirected by the application of fungicides (Köhle et al., 2002), and these modifications are reflected in the pre-harvest characteristics, such as extended 
Table 1. Effect of fungicides on polyamines content $\left(\mathrm{mg} \mathrm{kg}^{-1} \mathrm{FW}\right)$ of cauliflower cultivar Flamenco at different post-harvest times.

\begin{tabular}{lllllll}
\hline \multirow{2}{*}{ Polyamines } & \multicolumn{5}{c}{ Treatments } \\
\cline { 2 - 7 } & $\mathrm{DPH}$ & $\mathrm{C}$ & $\mathrm{B}$ & $\mathrm{F}+\mathrm{P}$ & $\mathrm{M}+\mathrm{P}$ & $\mathrm{M}+\mathrm{P}+\mathrm{B}$ \\
\hline \multirow{3}{*}{ Putrescine } & 0 & $13.7 \pm 1.1^{\mathrm{Aa} a^{*}}$ & $7.4 \pm 0.5^{\mathrm{Ba}}$ & $7.6 \pm 0.4^{\mathrm{Ba}}$ & $7.5 \pm 0.7^{\mathrm{Ba}}$ & $7.3 \pm 0.2^{\mathrm{Ba}}$ \\
& $3+3$ & $6.6 \pm 0.5^{\mathrm{Ab}}$ & $4.2 \pm 0.4^{\mathrm{CC}}$ & $4.7 \pm 0.2^{\mathrm{BCb}}$ & $5.3 \pm 0.7^{\mathrm{ABCb}}$ & $5.7 \pm 0.5^{\mathrm{ABb}}$ \\
& $9+3$ & $7.5 \pm 0.4^{\mathrm{Ab}}$ & $5.4 \pm 0.7^{\mathrm{Bb}}$ & $5.1 \pm 0.5^{\mathrm{BCb}}$ & $4.0 \pm 0.6^{\mathrm{Cc}}$ & $3.9 \pm 0.3^{\mathrm{Cc}}$ \\
\hline \multirow{3}{*}{ Spermidine } & 0 & $17.1 \pm 1.1^{\mathrm{Cb}}$ & $15.4 \pm 0.4^{\mathrm{Cb}}$ & $17.4 \pm 0.5^{\mathrm{Cb}}$ & $30.9 \pm 1.7^{\mathrm{Ac}}$ & $23.8 \pm 0.7^{\mathrm{BC}}$ \\
& $3+3$ & $30.6 \pm 1.6^{\mathrm{Ca}}$ & $39.2 \pm 1.5^{\mathrm{Aa}}$ & $37.8 \pm 1.4^{\mathrm{ABa}}$ & $37.0 \pm 0.6^{\mathrm{ABb}}$ & $33.9 \pm 2.7^{\mathrm{BCb}}$ \\
& $9+3$ & $28.4 \pm 0.9^{\mathrm{Ca}}$ & $40.1 \pm 1.2^{\mathrm{Aa}}$ & $34.4 \pm 3.0^{\mathrm{Ba}}$ & $41.8 \pm 2.9^{\mathrm{Aa}}$ & $41.3 \pm 5.0^{\mathrm{Aa}}$ \\
\hline \multirow{3}{*}{ Spermine } & 0 & $2.6 \pm 0.4^{\mathrm{BC}}$ & $4.4 \pm 0.6^{\mathrm{ABC}}$ & $5.2 \pm 0.3^{\mathrm{Ab}}$ & $6.4 \pm 1.1^{\mathrm{Ac}}$ & $5.2 \pm 0.6^{\mathrm{Ac}}$ \\
& $3+3$ & $12.2 \pm 1.4^{\mathrm{Da}}$ & $17.5 \pm 0.6^{\mathrm{Ab}}$ & $16.0 \pm 0.7^{\mathrm{ABa}}$ & $14.9 \pm 0.8^{\mathrm{BCb}}$ & $12.7 \pm 1.7^{\mathrm{CDb}}$ \\
& $9+3$ & $9.6 \pm 1.6^{\mathrm{Db}}$ & $19.9 \pm 1.3^{\mathrm{Ba}}$ & $13.8 \pm 1.3^{\mathrm{Ca}}$ & $21.3 \pm 1.0^{\mathrm{Ba}}$ & $26.9 \pm 0.6^{\mathrm{Aa}}$ \\
\hline
\end{tabular}

* Means \pm SD followed by same letter, lowercase in the column and uppercase in the line, are not significantly different by Tukey test at $5 \%$ probability. C: control (without application of fungicides); B: boscalid; F + P: fluxapyroxad + pyraclostrobin; $M+P$ : metiram + pyraclostrobin; $M+P+B:$ metiram + pyraclostrobin + boscalid; DPH: days post-harvest.

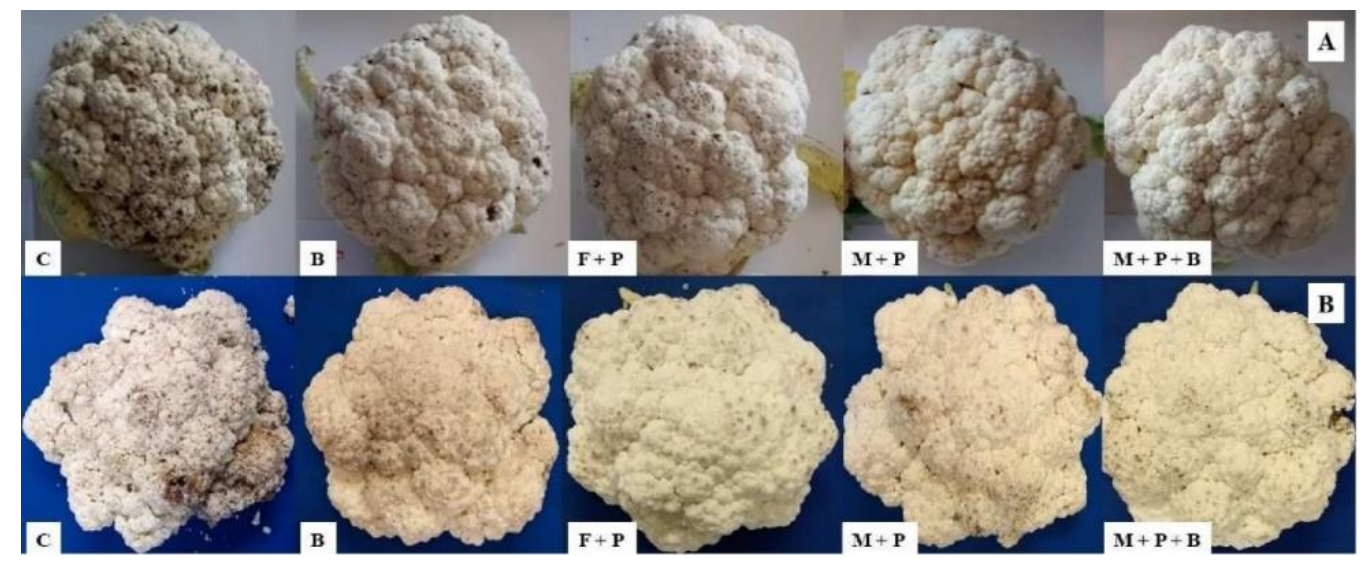

Fig 1. Visual quality decay as a result of the fungicide applied $(C, B, F+P, M+P$ and $M+P+B)$ in the cauliflower cultivars Flamenco (A) and Verona (B) at 12 days of storage ( 9 days of storage +3 days of commercial simulation).

Table 2. Effect of fungicides on polyamines content ( $\left.\mathrm{mg} \mathrm{kg}^{-1} \mathrm{FW}\right)$ of cauliflower cultivar Verona at different post-harvest times.

\begin{tabular}{|c|c|c|c|c|c|c|}
\hline \multirow{2}{*}{ Polyamines } & \multicolumn{3}{|c|}{ Treatments } & \multirow[b]{2}{*}{$F+P$} & \multirow[b]{2}{*}{$M+P$} & \multirow[b]{2}{*}{$M+P+B$} \\
\hline & DPH & C & $B$ & & & \\
\hline & 0 & $12.5 \pm 0.9^{\mathrm{Ea}^{*}}$ & $21.8 \pm 0.3^{\mathrm{Aa}}$ & $15.7 \pm 0.8^{\mathrm{Da}}$ & $17.9 \pm 0.7^{\mathrm{Ca}}$ & $19.8 \pm 0.1^{\mathrm{Ba}}$ \\
\hline \multirow[t]{3}{*}{ Putrescine } & $3+3$ & $7.9 \pm 0.8^{\mathrm{Ab}}$ & $7.9 \pm 0.3^{\mathrm{Ab}}$ & $7.6 \pm 0.6^{\mathrm{Ab}}$ & $7.5 \pm 0.3^{\mathrm{Ab}}$ & $7.8 \pm 0.3^{\mathrm{Ab}}$ \\
\hline & $9+3$ & $12.6 \pm 0.8^{\mathrm{Aa}}$ & $7.0 \pm 1.2^{\mathrm{Bb}}$ & $7.1 \pm 0.3^{\mathrm{Bb}}$ & $6.5 \pm 0.5^{\mathrm{Bb}}$ & $7.3 \pm 0.6^{\mathrm{Bb}}$ \\
\hline & 0 & $57.9 \pm 4.1^{\mathrm{Ca}}$ & $92.4 \pm 5.0^{\mathrm{Aa}}$ & $81.1 \pm 5.1^{\mathrm{Ba}}$ & $89.4 \pm 3.2^{\mathrm{Aa}}$ & $86.4 \pm 4.9^{\mathrm{ABa}}$ \\
\hline \multirow[t]{3}{*}{ Spermidine } & $3+3$ & $57.7 \pm 4.9^{\mathrm{Aa}}$ & $63.8 \pm 4.3^{\mathrm{Ab}}$ & $59.8 \pm 1.5^{\mathrm{Ab}}$ & $44.7 \pm 3.2^{\mathrm{BC}}$ & $46.9 \pm 3.9^{\mathrm{Bc}}$ \\
\hline & $9+3$ & $56.2 \pm 0.8^{\mathrm{ABa}}$ & $53.0 \pm 3.3^{\mathrm{ABC}}$ & $50.0 \pm 1.1^{\mathrm{BC}}$ & $59.8 \pm 2.9^{\mathrm{Ab}}$ & $54.9 \pm 3.3^{\mathrm{ABb}}$ \\
\hline & 0 & $13.9 \pm 1.6^{\mathrm{Cb}}$ & $21.6 \pm 0.2^{\mathrm{Aa}}$ & $20.0 \pm 2.1^{\mathrm{ABa}}$ & $20.7 \pm 1.3^{\mathrm{ABb}}$ & $17.7 \pm 0.6^{\mathrm{Ba}}$ \\
\hline \multirow[t]{3}{*}{ Spermine } & $3+3$ & $16.3 \pm 2.2^{\mathrm{Bab}}$ & $18.5 \pm 0.5^{\mathrm{ABb}}$ & $21.1 \pm 1.1^{\mathrm{Aa}}$ & $16.7 \pm 0.7^{\mathrm{Bc}}$ & $18.0 \pm 1.7^{\mathrm{ABa}}$ \\
\hline & $9+3$ & $17.5 \pm 0.5^{\mathrm{Ca}}$ & $19.6 \pm 1.0^{\mathrm{BCab}}$ & $21.1 \pm 1.0^{\mathrm{Ba}}$ & $27.2 \pm 1.9^{\mathrm{Aa}}$ & $19.6 \pm 1.5^{\mathrm{BCa}}$ \\
\hline & 0 & $3.3 \pm 0.2^{\mathrm{Bab}}$ & $4.5 \pm 0.2^{\mathrm{Aa}}$ & $3.9 \pm 0.2^{\mathrm{ABa}}$ & $4.5 \pm 0.2^{\mathrm{Aa}}$ & $4.6 \pm 0.2^{\mathrm{Aa}}$ \\
\hline \multirow[t]{2}{*}{ Histamine } & $3+3$ & $3.6 \pm 0.2^{\mathrm{Aa}}$ & $3.3 \pm 0.4^{\mathrm{Ab}}$ & $3.4 \pm 1.3^{\mathrm{Aa}}$ & $1.9 \pm 0.2^{\mathrm{Bb}}$ & $1.9 \pm 0.3^{\mathrm{Bb}}$ \\
\hline & $9+3$ & $2.6 \pm 0.6^{\mathrm{Ab}}$ & $1.7 \pm 0.4^{\mathrm{Ac}}$ & $1.7 \pm 0.1^{\mathrm{Ab}}$ & $1.9 \pm 0.3^{\mathrm{Ab}}$ & $1.8 \pm 0.2^{\mathrm{Ab}}$ \\
\hline
\end{tabular}

* Means \pm SD followed by same letter, lowercase in the column and uppercase in the line, are not significantly different by Tukey test at $5 \%$ probability. C: control (without application of fungicides); B: boscalid; F + P: fluxapyroxad + pyraclostrobin; $M+P$ : metiram + pyraclostrobin; $M+P+B$ : metiram + pyraclostrobin + boscalid; DPH: days post-harvest. 
Table 3. Effect of fungicides on peroxidase $\left(\mu \mathrm{mol} \mathrm{H} \mathrm{H}_{2} \mathrm{~min}^{-1}\right.$. $\mathrm{g}^{-1} \mathrm{FW}$ ) and polyphenoloxidase (units/g) of cultivars Flamenco and Verona at different post-harvest times.

\begin{tabular}{|c|c|c|c|c|c|c|c|c|c|c|}
\hline \multirow{3}{*}{ Treatments } & \multicolumn{10}{|c|}{ Days of post-harvest } \\
\hline & 0 & 3 & $3+3$ & $6+3$ & $9+3$ & 0 & 3 & $3+3$ & $6+3$ & $9+3$ \\
\hline & \multicolumn{5}{|c|}{ POD } & \multicolumn{5}{|c|}{ PPO } \\
\hline & \multicolumn{10}{|c|}{ Flamenco } \\
\hline C & $1.0 \pm 0.1^{\mathrm{Cab}^{*}}$ & $2.3 \pm 0.3^{\mathrm{Aab}}$ & $2.6 \pm 0.1^{\mathrm{Aa}}$ & $1.8 \pm 0.0^{\mathrm{Ba}}$ & $1.4 \pm 0.3^{\mathrm{BCa}}$ & $281.8 \pm 13.0^{\mathrm{Ca}}$ & $508.0 \pm 38.8^{\mathrm{Aa}}$ & $493.0 \pm 34.7^{\mathrm{ABa}}$ & $299.7 \pm 23.5^{\mathrm{Cab}}$ & $435.3 \pm 48.2^{\mathrm{Ba}}$ \\
\hline B & $0.6 \pm 0.1^{\mathrm{Cb}}$ & $2.6 \pm 0.2^{\mathrm{Aa}}$ & $1.1 \pm 0.4^{\mathrm{Bb}}$ & $1.4 \pm 0.2^{\mathrm{Ba}}$ & $1.3 \pm 0.0^{\mathrm{Ba}}$ & $267.9 \pm 26.2^{\mathrm{Da}}$ & $502.5 \pm 36.8^{\mathrm{Aa}}$ & $367.0 \pm 36.3^{\mathrm{BCb}}$ & $306.3 \pm 39.6^{\text {DCab }}$ & $402.7 \pm 31.3^{\text {Bab }}$ \\
\hline$F+P$ & $0.6 \pm 0.3^{\mathrm{Cab}}$ & $2.2 \pm 0.5^{\mathrm{Aabc}}$ & $1.3 \pm 0.0^{\mathrm{Bb}}$ & $1.6 \pm 0.2^{\mathrm{Ba}}$ & $0.5 \pm 0.2^{\mathrm{cb}}$ & $202.6 \pm 38.0^{\mathrm{Bb}}$ & $331.1 \pm 22.6^{\mathrm{Ab}}$ & $348.5 \pm 25.5^{\mathrm{Ab}}$ & $334.9 \pm 26.0^{\mathrm{Aa}}$ & $343.4 \pm 36.9^{\mathrm{Abc}}$ \\
\hline$M+P$ & $0.7 \pm 0.1^{\mathrm{Bab}}$ & $1.8 \pm 0.3^{\mathrm{Ac}}$ & $0.5 \pm 0.3^{\mathrm{Bc}}$ & $0.5 \pm 0.2^{\mathrm{Bb}}$ & $0.5 \pm 0.2^{\mathrm{Bb}}$ & $198.7 \pm 21.3^{\mathrm{Bb}}$ & $346.0 \pm 37.5^{\mathrm{Ab}}$ & $233.8 \pm 31.1^{\mathrm{BC}}$ & $217.1 \pm 31.5^{\mathrm{BC}}$ & $299.2 \pm 12.0^{\mathrm{Ac}}$ \\
\hline \multirow[t]{2}{*}{$M+P+B$} & $1.0 \pm 0.1^{\mathrm{BCa}}$ & $1.9 \pm 0.7^{\mathrm{Abc}}$ & $0.9 \pm 0.1^{\mathrm{BCbC}}$ & $0.6 \pm 0.2^{\mathrm{cb}}$ & $1.2 \pm 0.3^{\mathrm{Ba}}$ & $242.3 \pm 34.7^{\mathrm{Cab}}$ & $340.3 \pm 33.0^{\mathrm{Ab}}$ & $321.5 \pm 24.9^{\mathrm{ABb}}$ & $260.4 \pm 40.2^{\mathrm{BCbc}}$ & $356.9 \pm 26.4^{\mathrm{Abc}}$ \\
\hline & \multicolumn{10}{|c|}{ Verona } \\
\hline C & $1.2 \pm 0.2^{\mathrm{Ca}}$ & $2.4 \pm 0.4^{\mathrm{Ba}}$ & $2.3 \pm 0.1^{\mathrm{Ba}}$ & $3.0 \pm 0.7^{\mathrm{Aa}}$ & $3.1 \pm 0.2^{\mathrm{Aa}}$ & $382.4 \pm 20.1^{\mathrm{BCa}}$ & $349.0 \pm 19.1^{\mathrm{Cab}}$ & $447.8 \pm 21.8^{\mathrm{Aa}}$ & $378.0 \pm 26.2^{\mathrm{BCa}}$ & $429.8 \pm 24.2^{\mathrm{Aba}}$ \\
\hline B & $0.7 \pm 0.1^{\mathrm{cbc}}$ & $0.9 \pm 0.2^{\mathrm{BCC}}$ & $1.2 \pm 0.3^{\mathrm{Bbc}}$ & $1.3 \pm 0.2^{\mathrm{Bbc}}$ & $1.8 \pm 0.2^{\mathrm{Ab}}$ & $332.1 \pm 25.4^{\mathrm{ABab}}$ & $383.1 \pm 37.5^{\text {Аa }}$ & $341.0 \pm 14.6^{\mathrm{ABbc}}$ & $307.6 \pm 25.9^{\mathrm{Bb}}$ & $346.3 \pm 42.8^{\mathrm{ABb}}$ \\
\hline$F+P$ & $0.7 \pm 0.1^{\mathrm{Bc}}$ & $0.6 \pm 0.2^{\mathrm{BC}}$ & $1.4 \pm 0.3^{\mathrm{Ab}}$ & $1.3 \pm 0.0^{\mathrm{Abc}}$ & $1.6 \pm 0.1^{\mathrm{Ab}}$ & $346.8 \pm 28.1^{\mathrm{Aa}}$ & $277.7 \pm 34.7^{\mathrm{BC}}$ & $402.8 \pm 37.6^{\mathrm{Aab}}$ & $284.6 \pm 35.2^{\mathrm{Bb}}$ & $363.7 \pm 18.3^{\mathrm{Aab}}$ \\
\hline$M+P$ & $0.9 \pm 0.1^{\mathrm{Ab}}$ & $1.6 \pm 0.0^{\mathrm{ABb}}$ & $1.1 \pm 0.2^{\mathrm{BCbc}}$ & $1.9 \pm 0.1^{\mathrm{Ab}}$ & $1.7 \pm 0.4^{\mathrm{Ab}}$ & $350.9 \pm 25.3^{\mathrm{ABa}}$ & $311.1 \pm 39.0^{\mathrm{ABbc}}$ & $348.6 \pm 37.8^{\mathrm{ABbc}}$ & $305.0 \pm 19.6^{\mathrm{Bb}}$ & $366.3 \pm 29.1^{\mathrm{Aab}}$ \\
\hline$M+P+B$ & $0.3 \pm 0.1^{\mathrm{Cd}}$ & $0.6 \pm 0.1^{\mathrm{ABC}}$ & $0.9 \pm 0.2^{\mathrm{BC}}$ & $0.6 \pm 0.3^{\mathrm{BCC}}$ & $1.8 \pm 0.3^{\mathrm{Ab}}$ & $287.3 \pm 22.0^{\mathrm{Bb}}$ & $265.3 \pm 31.7^{\mathrm{BC}}$ & $310.8 \pm 32.8^{\mathrm{BC}}$ & $269.4 \pm 22.2^{\mathrm{Bb}}$ & $396.2 \pm 27.1^{\mathrm{Aab}}$ \\
\hline
\end{tabular}

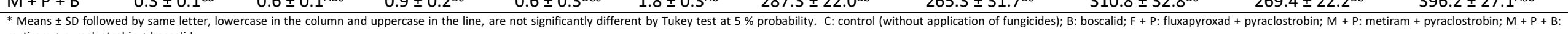

Table 4. Percent weight loss of cultivars Flamenco and Verona at different post-harvest times and with different fungicides applied.

\begin{tabular}{|c|c|c|c|c|}
\hline \multirow{2}{*}{ Treatments } & \multicolumn{4}{|c|}{ Days of post-harvest } \\
\hline & 3 & $3+3$ & $6+3$ & $9+3$ \\
\hline \multicolumn{5}{|l|}{ Flamenco } \\
\hline C & $3.51 \pm 0.11^{\mathrm{Da}^{*}}$ & $7.14 \pm 0.37^{c}$ & $14.93 \pm 0.63^{\mathrm{Ba}}$ & $22.13 \pm 0.88^{\mathrm{Aa}}$ \\
\hline B & $3.31 \pm 0.38^{\mathrm{Dab}}$ & $6.86 \pm 0.94^{c}$ & $12.82 \pm 0.45^{\mathrm{Bb}}$ & $19.10 \pm 2.48^{\mathrm{Aab}}$ \\
\hline$F+P$ & $2.93 \pm 0.47^{\mathrm{Db}}$ & $6.41 \pm 0.84^{c}$ & $13.49 \pm 0.69^{\mathrm{Bab}}$ & $19.98 \pm 1.31^{\text {Aab }}$ \\
\hline$M+P$ & $3.42 \pm 0.26^{\mathrm{Dab}}$ & $7.21 \pm 0.63^{c}$ & $13.86 \pm 1.06^{\mathrm{Bab}}$ & $18.91 \pm 0.91^{\mathrm{Ab}}$ \\
\hline$M+P+B$ & $3.46 \pm 0.07^{\mathrm{Dab}}$ & $7.62 \pm 0.15^{c}$ & $14.02 \pm 0.15^{\mathrm{Bab}}$ & $19.47 \pm 0.65^{\text {Aab }}$ \\
\hline \multicolumn{5}{|l|}{ Verona } \\
\hline $\mathrm{C}$ & $4.21 \pm 0.31^{\mathrm{Da}}$ & $9.52 \pm 0.74^{C}$ & $13.94 \pm 1.09^{B}$ & $22.96 \pm 0.67 \mathrm{Aa}$ \\
\hline B & $3.33 \pm 0.31^{\mathrm{Dab}}$ & $8.73 \pm 0.98^{c}$ & $12.72 \pm 1.06^{\mathrm{B}}$ & $20.60 \pm 0.99^{\mathrm{Ab}}$ \\
\hline$F+P$ & $3.31 \pm 0.39^{\mathrm{Dab}}$ & $9.01 \pm 0.94^{C}$ & $13.37 \pm 0.85^{B}$ & $20.87 \pm 0.81^{\text {Aab }}$ \\
\hline$M+P$ & $3.10 \pm 0.41^{\mathrm{Db}}$ & $7.98 \pm 0.60^{C}$ & $11.91 \pm 0.86^{B}$ & $19.42 \pm 0.78^{\mathrm{Ab}}$ \\
\hline$M+P+B$ & $3.50 \pm 0.55^{\mathrm{Dab}}$ & $8.38 \pm 0.73^{c}$ & $12.77 \pm 0.47^{\mathrm{B}}$ & $20.99 \pm 0.95^{\text {Aab }}$ \\
\hline
\end{tabular}


Table 5. Soluble solids ('Brix), titratable acidity (percentage) and $\mathrm{pH}$ of cultivars Flamenco and Verona at different post-harvest times and with different fungicides applied.

\begin{tabular}{|c|c|c|c|c|c|}
\hline \multirow{2}{*}{ Treatments } & \multicolumn{5}{|c|}{ Days of post-harvest } \\
\hline & 0 & 3 & 6 & 9 & 12 \\
\hline \multicolumn{6}{|l|}{ Verona } \\
\hline & \multicolumn{5}{|c|}{ Soluble solids (SS) } \\
\hline C & $4.15 \pm 0.37^{\mathrm{Bbc}} *$ & $4.40 \pm 0.45^{\mathrm{Bb}}$ & $3.80 \pm 1.33^{\mathrm{B}}$ & $6.40 \pm 0.66^{A}$ & $5.68 \pm 0.85^{\mathrm{Ab}}$ \\
\hline B & $4.88 \pm 0.67^{\mathrm{Cab}}$ & $6.40 \pm 0.62^{\mathrm{ABa}}$ & $3.35 \pm 0.31^{\mathrm{D}}$ & $5.68 \pm 0.77^{\mathrm{BC}}$ & $7.25 \pm 0.47^{\mathrm{Aa}}$ \\
\hline$F+P$ & $3.70 \pm 0.24^{\mathrm{Cc}}$ & $5.88 \pm 0.05^{\mathrm{Ba}}$ & $4.08 \pm 0.75^{C}$ & $6.05 \pm 0.65^{\mathrm{B}}$ & $7.28 \pm 0.60^{\mathrm{Aa}}$ \\
\hline$M+P$ & $4.48 \pm 0.59^{\mathrm{Babc}}$ & $5.55 \pm 0.52^{\mathrm{Bab}}$ & $5.00 \pm 0.65^{\mathrm{B}}$ & $7.25 \pm 0.33^{\mathrm{A}}$ & $6.80 \pm 0.24^{\mathrm{Aab}}$ \\
\hline \multirow[t]{2}{*}{$M+P+B$} & $5.28 \pm 0.34^{\mathrm{BCa}}$ & $6.20 \pm 0.66^{\mathrm{ABa}}$ & $4.30 \pm 0.33^{C}$ & $6.63 \pm 0.88^{A}$ & $6.93 \pm 0.46^{\mathrm{Aa}}$ \\
\hline & \multicolumn{5}{|c|}{ Titratable acidity (TA) } \\
\hline C & $0.21 \pm 0.02^{a}$ & $0.17 \pm 0.05$ & $0.23 \pm 0.03^{a}$ & $0.20 \pm 0.00^{a}$ & $0.18 \pm 0.02$ \\
\hline B & $0.16 \pm 0.05^{\mathrm{ab}}$ & $0.15 \pm 0.00$ & $0.20 \pm 0.00^{\mathrm{ab}}$ & $0.15 \pm 0.00^{b}$ & $0.17 \pm 0.03$ \\
\hline$F+P$ & $0.17 \pm 0.03^{\mathrm{ABab}}$ & $0.13 \pm 0.03^{\mathrm{B}}$ & $0.19 \pm 0.06^{\mathrm{Aab}}$ & $0.18 \pm 0.03^{\mathrm{Aab}}$ & $0.21 \pm 0.03^{\mathrm{A}}$ \\
\hline$M+P$ & $0.15 \pm 0.03^{\mathrm{ab}}$ & $0.19 \pm 0.04$ & $0.16 \pm 0.00^{\mathrm{ab}}$ & $0.18 \pm 0.02^{\mathrm{ab}}$ & $0.19 \pm 0.00$ \\
\hline \multirow[t]{2}{*}{$M+P+B$} & $0.11 \pm 0.03^{\mathrm{Bb}}$ & $0.16 \pm 0.02^{\mathrm{AB}}$ & $0.14 \pm 0.02^{\mathrm{ABb}}$ & $0.15 \pm 0.00^{\mathrm{ABb}}$ & $0.18 \pm 0.03^{\mathrm{A}}$ \\
\hline & \multicolumn{5}{|l|}{$\mathrm{pH}$} \\
\hline C & $7.37 \pm 0.12^{\mathrm{Aa}}$ & $7.14 \pm 0.07^{B}$ & $6.83 \pm 0.06^{\mathrm{Ca}}$ & $6.74 \pm 0.10^{\mathrm{Cab}}$ & $6.88 \pm 0.07^{c}$ \\
\hline B & $7.33 \pm 0.02^{\mathrm{Aab}}$ & $7.12 \pm 0.09^{B}$ & $6.71 \pm 0.04^{\mathrm{Cab}}$ & $6.82 \pm 0.07^{\mathrm{Ca}}$ & $6.73 \pm 0.03^{c}$ \\
\hline$F+P$ & $7.38 \pm 0.06^{\mathrm{Aa}}$ & $7.15 \pm 0.11^{\mathrm{B}}$ & $6.77 \pm 0.14^{\text {Cab }}$ & $6.62 \pm 0.09^{\mathrm{Db}}$ & $6.71 \pm 0.06^{C D}$ \\
\hline$M+P$ & $7.08 \pm 0.17^{A b}$ & $7.08 \pm 0.02^{A}$ & $6.70 \pm 0.06^{\mathrm{Bab}}$ & $6.74 \pm 0.03^{\mathrm{Bab}}$ & $6.78 \pm 0.07^{B}$ \\
\hline$M+P+B$ & $7.34 \pm 0.06^{\mathrm{Aa}}$ & $7.04 \pm 0.06^{\mathrm{B}}$ & $6.62 \pm 0.07^{\mathrm{cb}}$ & $6.67 \pm 0.08^{\mathrm{Cab}}$ & $6.79 \pm 0.10^{c}$ \\
\hline \multicolumn{6}{|l|}{ Flamenco } \\
\hline SS & $5.54 \pm 0.26^{\mathrm{B}}$ & $5.63 \pm 0.25^{\mathrm{B}}$ & $6.32 \pm 0.23^{A}$ & $5.59 \pm 0.12^{\mathrm{B}}$ & $5.67 \pm 0.18^{B}$ \\
\hline TA & $0.24 \pm 0.01^{\mathrm{AB}}$ & $0.26 \pm 0.02^{A}$ & $0.20 \pm 0.02^{c}$ & $0.22 \pm 0.01^{\mathrm{BC}}$ & $0.19 \pm 0.01^{c}$ \\
\hline $\mathrm{pH}$ & $6.86 \pm 0.03^{A}$ & $6.27 \pm 0.08^{C}$ & $6.52 \pm 0.14^{B}$ & $6.30 \pm 0.11^{c}$ & $6.40 \pm 0.03^{\mathrm{BC}}$ \\
\hline
\end{tabular}

fungicides); B: boscalid; F + P: fluxapyroxad + pyraclostrobin; $M+P$ : metiram + pyraclostrobin; $M+P+B$ : metiram + pyraclostrobin + boscalid.

Table 6. Vitamin C (mg $100 \mathrm{~g}^{-1}$ ) of cultivars Flamenco and Verona at different post-harvest times and with different fungicides applied.

\begin{tabular}{|c|c|c|c|c|c|}
\hline \multirow{2}{*}{ Treatments } & \multicolumn{5}{|c|}{ Days of post-harvest } \\
\hline & 0 & 3 & $3+3$ & $6+3$ & $9+3$ \\
\hline \multicolumn{6}{|l|}{ Flamenco } \\
\hline $\mathrm{C}$ & $30.43 \pm 1.17^{\mathrm{Ad}^{*}}$ & $22.00 \pm 1.39^{B}$ & $19.5 \pm 1.29^{B}$ & $15.86 \pm 1.51^{C}$ & $10.09 \pm 1.17^{\mathrm{Db}}$ \\
\hline B & $34.04 \pm 1.38^{\mathrm{Abc}}$ & $23.26 \pm 1.04^{B}$ & $20.1 \pm 0.03^{c}$ & $16.45 \pm 2.30^{\mathrm{D}}$ & $11.89 \pm 0.01^{\text {Eab }}$ \\
\hline$F+P$ & $36.96 \pm 2.24^{\mathrm{Ab}}$ & $23.19 \pm 1.01^{\mathrm{B}}$ & $20.1 \pm 2.06 \mathrm{C}$ & $16.41 \pm 1.23^{\mathrm{D}}$ & $13.07 \pm 1.37$ Еа \\
\hline$M+P$ & $33.62 \pm 1.40^{\mathrm{Ac}}$ & $23.33 \pm 1.39^{\mathrm{B}}$ & $20.6 \pm 1.26^{B}$ & $17.44 \pm 1.18^{C}$ & $12.47 \pm 2.28^{\mathrm{Dab}}$ \\
\hline$M+P+B$ & $40.18 \pm 1.29^{A a}$ & $23.14 \pm 1.09^{\mathrm{B}}$ & $20.1 \pm 2.08^{C}$ & $16.57 \pm 2.44^{\mathrm{D}}$ & $13.05 \pm 1.35^{\text {Еа }}$ \\
\hline \multicolumn{6}{|l|}{ Verona } \\
\hline C & $28.33 \pm 0.15^{A}$ & $21.59 \pm 1.52^{B}$ & $7.41 \pm 0.10^{\mathrm{Cb}}$ & $7.20 \pm 0.21^{\mathrm{cb}}$ & $5.23 \pm 0.39^{D}$ \\
\hline B & $29.82 \pm 1.52^{\mathrm{A}}$ & $22.15 \pm 1.21^{\mathrm{B}}$ & $8.26 \pm 1.11^{\mathrm{cb}}$ & $7.42 \pm 0.30^{\mathrm{cb}}$ & $5.29 \pm 0.60^{D}$ \\
\hline$F+P$ & $29.44 \pm 1.26^{A}$ & $23.34 \pm 1.25^{\mathrm{B}}$ & $9.27 \pm 1.35^{\mathrm{Cab}}$ & $7.51 \pm 0.30^{\mathrm{cb}}$ & $5.21 \pm 0.46^{\mathrm{D}}$ \\
\hline$M+P$ & $28.88 \pm 1.30^{A}$ & $21.94 \pm 1.15^{\mathrm{B}}$ & $9.11 \pm 1.22^{\mathrm{Cab}}$ & $8.38 \pm 0.66^{\mathrm{Ca}}$ & $5.43 \pm 0.46^{\mathrm{D}}$ \\
\hline$M+P+B$ & $28.39 \pm 0.18^{A}$ & $21.61 \pm 1.56^{\mathrm{B}}$ & $11.14 \pm 1.32^{\mathrm{Ca}}$ & $7.59 \pm 0.26^{\mathrm{Db}}$ & $5.31 \pm 0.47^{E}$ \\
\hline
\end{tabular}

* Means $\pm S D$ followed by same letter, lowercase in the column and uppercase in the line, are not significantly different by Tukey test at $5 \%$ probability. C: control (without application of fungicides);

B: boscalid; F + P: fluxapyroxad + pyraclostrobin; M + P: metiram + pyraclostrobin; M + P + B: metiram + pyraclostrobin + boscalid.

commercial quality, water retention and increased protein and vitamin content. However, as verified in the physicochemical parameters discussed above, these effects were not evident in cultivar Flamenco and Verona after storage and simulated commercialization. Physicochemical characteristics are intrinsic to each cultivar and independent of the applied handling, which could explain the results obtained in cv. Verona, showing that the plant's vigor is related to a higher response to the agrochemicals.

\section{Materials and Methods}

\section{Plant material, experimental treatments and growth conditions}

The experiment was performed using two cauliflower cultivars (cv.) [(Brassica oleracea L. var. botrytis) cv. Flamenco $^{\circ}$ (Bejo) and $\mathrm{cv}$. Verona ${ }^{\circ}$ (Seminis)], which were cultivated in Pardinho, Sao Paulo ( $23^{\circ} 02^{\prime} 31.1^{\prime \prime} \mathrm{S}, 48^{\circ} 22^{\prime}$ $55.5^{\prime \prime} \mathrm{W}$ at $912 \mathrm{~m}$ of altitude), Brazil. The climate of São Paulo is Cwa, subtropical humid (mesothermal) according to Köppen's classification. 
Cultivar Flamenco was cultivated during the winter of 2015 (middle of May to end of August) and cv. Verona during the summer of 2016 (beginning of February to middle of May). Both cultivars presented the same cycle but with different genetic characteristics. After soil analysis, the fertilization was performed according to May et al. (2007), using $84 \mathrm{~kg} \mathrm{~N}$, $294 \mathrm{~kg} \mathrm{P}_{2} \mathrm{O}_{5}$ and $168 \mathrm{~kg} \mathrm{~K}_{2} \mathrm{O}$ per hectare for both cultivars. Both cultivars were seeded (one seed per cell) in commercial trays of expanded polystyrene (128 cells) in a greenhouse and using commercial substrate (Tropstrato ${ }^{\circ}$ HA Hortaliças, Brazil). After 30 days, the seedlings (four true leaves, without foliar diseases) were transplanted to the field at 0.6 $\mathrm{m} \times 0.4 \mathrm{~m}$ (rows $\times$ line) $\left(41,666\right.$ plants ha $\left.{ }^{-1}\right)$. The planting was performed in an open field and irrigated by a sprinkling system when necessary (approximately $7 \mathrm{~mm}$ day $^{-1}$ ). The weed control was done manually using hoes. During the experiment, five treatments were applied using four different fungicides or combinations of fungicides and one control (not pulverized), (i.e., control - without fungicide), boscalid (Cantus ${ }^{\circ}$ ) $\left(0.3 \mathrm{~g} \mathrm{~L}^{-1}\right)$, pyraclostrobin + fluxapyroxad (Orkestra $\left.{ }^{\circ} \mathrm{SC}\right)\left(0.3 \mathrm{~mL} \mathrm{~L}^{-1}\right)$, metiram + pyraclostrobin Cabrio ${ }^{\circ}$ Top $\left(3.0 \mathrm{~g} \mathrm{~L}^{-1}\right)$ and metiram + pyraclostrobin + boscalid (Cantus ${ }^{\circ}\left(0.3 \mathrm{~g} \mathrm{~L}^{-1}\right)+$ Cabrio $^{\circ}$ Top $\left.\left(3.0 \mathrm{~g} \mathrm{~L}^{-1}\right)\right)$. The treatments were applied to the seedlings 18 days after sowing and at the beginning of cauliflower flowering in the field ( 30 days before harvest) for both cultivars.

\section{Cauliflower harvest and storage}

The inflorescences were harvested 102 days after the sowing. The harvest time was defined when the inflorescence was compact and with a transversal diameter $\geq 15 \mathrm{~cm}$. After the harvest, the inflorescences were stored for 9 days in cold room $\left(10 \pm 2{ }^{\circ} \mathrm{C}\right.$ and $\left.92 \pm 2 \% \mathrm{RH}\right)$. Every three days (i.e., on days 3,6 , and 9), part of the inflorescences were removed from the cold room and kept for three more days at room temperature to simulate commercialization, establishing the following days of analysis $0,0+3,3+3,6+3$ and $9+3$ (storage + simulated commercialization). The analyses of enzymatic activity, weight loss and physicochemical characteristics were performed in each treatment at the moment of the harvest (day 0 ) and at $0+3,3+3,6+3$ and $9+3$ days. The polyamines were determined in three storage periods $(0,3+$ 3 and $9+3$ days). The inflorescences (eight per treatment) were ground and frozen by liquid nitrogen and stored at -80 ${ }^{\circ} \mathrm{C}$ until analysis.

\section{Experimental design}

The experimental design was completely randomized in a $5 \mathrm{x}$ 5 factorial scheme, with 5 treatments (control - without fungicide, boscalid, pyraclostrobin + fluxapyroxad, metiram + pyraclostrobin and metiram + pyraclostrobin + boscalid) and five times of storage $(0,0+3,3+3,6+3$ and $9+3$ days of storage + simulated commercialization), with 4 replications composed by two inflorescences. Cultivar Flamenco and Verona have different biometric and genetic characteristics; thus, the results were separately analyzed and discussed according to the treatments and periods for each cultivar.

\section{Analyses}

\section{Determination of polyamines}

The inflorescences were frozen by liquid nitrogen and stored at $-80{ }^{\circ} \mathrm{C}$ until analysis. The polyamines putrescine (Put), spermidine (Spd), spermine (Spm) and histamine (His) were extracted and isolated according to Lima et al. (2008) and analyzed according to Ferreira et al. (2016).

\section{Enzymatic activity}

In order to determine the polyphenoloxidase (PPO, EC 1.14.18.1) and peroxidase (POD, EC 1.11.1.7) activity, 200 $\mathrm{mg}$ of the fresh inflorescence was homogenized in $0.2 \mathrm{M}$ potassium phosphate buffer $(\mathrm{pH}$ 6.7) and subsequently centrifuged $\left(6000 \mathrm{~g}, 20 \mathrm{~min}\right.$ at $4{ }^{\circ} \mathrm{C}$ ) (Mikro 220R, Hettich Zentrifugen, Tuttlingen, Germany). The PPO activity was determined according to Lee et al. (1990) and expressed in units/g. The peroxidase activity were evaluated as described by Lima et al. (1999) and the results expressed in $\mu \mathrm{mol} \mathrm{H}_{2} \mathrm{O}_{2}$ $\mathrm{min}^{-1} \mathrm{~g}^{-1} \mathrm{FW}$. All the readings were performed with a spectrophotometer UV-VIS (Ultrospec 2000, Amersham Pharmacia Biotech, Freiburg, Germany).

\section{Presence/absence of fungicides}

Dry samples were ground in a mill and subjected to the extraction process with $\mathrm{n}$-hexane. The fungicides were qualitatively identified using thin layer chromatography (TLC) (20 x 20 plate, 0.25 microns, $60 \mathrm{G}$, fluorescent), according to Moraes et al. (1991). The results were compared with the standards (Rf).

\section{Weight loss}

Cauliflower samples were weighed at harvest day (day 0), and the differences between days 3, 6, 9 and 12 were considered as weight loss (WL) and expressed as a percentage (IAL, 2008).

\section{Evaluations of physicochemical characteristics}

The physicochemical analyses were carried out according to the analytical recommendations of the Instituto Adolfo Lutz (IAL, 2008). Vitamin C content was determined using $10 \mathrm{~g}$ of frozen inflorescences homogenized with $10 \mathrm{~mL}$ of oxalic acid and 2,6-dychlorophenol-indophenol. The soluble solids were analyzed by digital refractometer (Atago model, PAL-1). The titratable acidity (TA) was determined using aliquots of $10 \mathrm{~g}$ of inflorescences, titrated with $0.1 \mathrm{~mol} \mathrm{~L}^{-1} \mathrm{NaOH}$ to $\mathrm{pH} 8.1$ and expressed in a percentage of citric acid. The $\mathrm{pH}$ was determined by digital potentiometer (ION model, pHB-500).

\section{Statistical analysis}

The analyses were carried out in triplicate $(n=3)$. The results were expressed as a mean $\pm \mathrm{SE}$. The obtained data were submitted to the variance analysis for comparison among the treatments and storage periods. For the variation sources, in which the F test indicated significance, the Tukey test was used. All the analyses were performed at the level of $5 \%$ of significance. 


\section{Conclusion}

This study found that fungicides have the potential to improve the post-harvest storage life and visual quality of cauliflowers. Results were dependent of the fungicide applied, although for cultivar Flamenco and Verona, the treatments $M+P+B$ and $F+P$ were the most efficient, respectively. Considering the parameters analyzed, we hypothesized that high Spd and Spm levels in treated samples are related to the post-harvest quality, when the activity of PPO and POD enzymes, which is associated with senescence, is similar to control. These findings may be useful as part of a strategy for fungal control in fields and for improving the post-harvest quality and shelf life of cauliflowers.

\section{Acknowledgements}

We acknowledge financial supports of National Council for Scientific and Technological Development (CNPq, Brazil) (130294/2015-2; 305177/2015-0) and Sao Paulo Research Fundation (FAPESP) (2016/22665-2).

\section{References}

Amri E, Shahsavar AR (2010) Response of Lime Seedlings (Citrus aurantifolia L.) to Exogenous Spermidine Treatments under Drought Stress. Plant Cell. 4(9):44834489.

Brackmann A, Trevisan JN, Martins GAK, De Freitas ST, De Mello AM (2005) Postharvest quality of 'Teresópolis gigante' cauliflower treated with ethylene, ethylene absorbent and 1-methylcyclopropene. Cienc Rural. 35(6):1444-1447.

Chen L, Zhang S (2010) Dissipation and residues of boscalid in strawberries and soils. Bulletin of environmental contamination and toxicology. 84(3): 301-304.

Domínguez I, Ferreres F, Pascual del Riquelme F, Font R, Gil MI (2012) Influence of preharvest application of fungicides on the postharvest quality of tomato (Solanum lycopersicum L.). Postharvest Biol Tec. 72:1-10.

Ferreira MI, Uliana MR, Costa SM, Magro M, Vianello F, Ming LC, Lima GPP (2016) Exclusion of solar UV radiation increases the yield of curcuminoid in Curcuma longa L. Ind Crop Prod. 89: 188-194.

Fu J, Li Z, Huang R, Wang S, Huang C, Cheng D, Zhang Z (2016) Dissipation, residue, and distribution of pyraclostrobin in banana and soil under field conditions in South China. Int J Environ An Ch. 96(14): 1367-1377.

Guimarães LRP, Soler JMP, Lima GPP, Pavan MA (2014) Polyamines in tomato plants grown during an incidence of tospovirus exposure. Eur J Plant Pathol. 140(4):701-709.

He M, Jia C, Zhao E, Chen L, Yu P, Jing J, Zheng Y (2016) Concentrations and dissipation of difenoconazole and fluxapyroxad residues in apples and soil, determined by ultrahigh-performance liquid chromatography electrospray ionization tandem mass spectrometry. Environ Sci Pollut R. 23(6): 5618-5626.

Huang H, Ge Z, Limwachiranon J, Li L, Li W, Luo Z (2017) UV$C$ treatment affects browning and starch metabolism of minimally processed lily bulb. Postharvest Postharvest Biol Tec. 128:105-111.
IAL - Instituto Adolfo Lutz (2008) Métodos químicos para análise de alimentos - Normas do Instituto Adolfo Lutz. In: Zenebon O, Pascuet NS, Tiglea P (eds), 1st edn. IMESP, São Paulo. 1020 p.

Jankowska M, Kaczynski P, Hrynko I, Lozowicka B (2016) Dissipation of six fungicides in greenhouse-grown tomatoes with processing and health risk. Environ Sci Pollut R. 23(12): 11885-11900.

Köhle H, Grossmann K, Jabs T, Gerhard M, Kaiser W, Glaab J, Conrath U, Seehaus K, Herms S (2002) Physiological effects of the strobilurin fungicide $\mathrm{F} 500$ on plants. In: Lyr H, Russell PE, Dehne H-W, Sisler HD (eds), 1st ed. Andover, UK. 61-74 p.

Latorre-Moratalla ML, Comas-Basté O, Bover-Cid S, VidalCarou MC (2017) Tyramine and histamine risk assessment related to consumption of dry fermented sausages by the Spanish population. Food Chem Toxicol. 99:78-85.

Lee CY, Kagan V, Jaworski AW, Brown SK (1990) Enzymatic browing in relation to phenolic compounds and polyphenoloxidase Activity amoung various peach cultivars. J Agric Food Chem. 38:99-101.

Li LL, Wang ML, Yu JL, Song GC, Li RJ (2013) Residue of Pyraclostrobin. Metiram 60\% WG in Garlic and Soil. Agrochemicals. 2: 14.

Li RJ, Yu JL, Song GC, Ma H (2010) Residue dynamics of pyraclostrobin in pyraclostrobin+ metiram in grape and soil. Environ Chem. 4: 619-622.

Lima GPP, Brasil, OG, de Oliveira AM (1999) Polyamines and peroxidase activity in bean (Phaseolus vulgaris L.) grown under saline stress. Sci Agr. 56(1):21-26.

Lima GPP, Costa SM, Monaco KA, Uliana MR, Fernandez RM, Correa, CR, Vianello F, Cisneros-Zevallos L, Minatel IO (2017) Cooking processes increase bioactive compounds in organic and conventional green beans. Int J Food Sci Nutr. 68(8):919-930.

Lima GPP, Da Rocha SA, Takaki M, Ramos PRR, Ono EO (2008) Comparison of polyamine, phenol and flavonoid contents in plants grown under conventional and organic methods. Int J Food Sci Tech. 43(10):1838-1843.

Lozowicka B, Jankowska M, Rutkowska E (2016) Investigations on fungicide removal from broccoli by various processing methods. Desalin Water Treat. 57(3): 1564-1572.

Marini F, Betti L, Scaramagli S, Biondi S, Torrigiani P (2001) Polyamine metabolism is upregulated in response to tobacco mosaic virus in hypersensitive, but not in susceptible, tobacco. New Phytol. 149(2):301-309.

May A, Tivelli SW, Vargas PF, Samra AG, Sacconi LV, Pinheiro MQ (2007) A Cultura da Couve-Flor. Boletim Técnico IAC, Campinas. $36 \mathrm{p}$.

Moraes EDCF, Sznelwar RB, de Fernícola NA (1991) Manual de toxicologia analítica. In Manual de toxicologia analítica. Livraria Roca, São Paulo. 241 p.

Moschou PN, Wu J, Cona A, Tavladoraki P, Angelini R, Roubelakis-Angelakis KA (2012) The polyamines and their catabolic products are significant players in the turnover of nitrogenous molecules in plants. J Exp Bot. 63(14):50035015.

Olarte C, Sanz S, Federico Echávarri J, Ayala F (2009) Effect of plastic permeability and exposure to light during storage on the quality of minimally processed broccoli and cauliflower. LWT-Food Sci Technol. 42(1):402-411. 
Ramos ARP, Amaro ACE, Macedo AC, De Assis Sugawara GS, Evangelista RM, Rodrigues JD, Ono EO (2013) Fruit quality of tomato 'giuliana' treated with products with physiological effects. Semin-Cienc Agrar. 34(6):3543-3552.

Sidana S, Bose J, Shabala L, Shabala S (2015) Nitric Oxide in Drought Stress Signalling and Tolerance in Plants. In: Khan MN, Mobin M, Mohammad F, Corpas FJ (eds) Nitric Oxide Action in Abiotic Stress Responses in Plants. Cham: Springer International Publishing. 95-114 p.

Szepesi Á, Gémes K, Orosz G, Peto A, Takács Z, Vorák M, Tari I (2011) Interaction between salicylic acid and polyamines and their possible roles in tomato hardening processes. Acta Biol Szeged. 55(1):165-166.

Teisseire H, Vernet $\mathrm{G}$ (2001) Effects of the fungicide folpet on the activities of antioxidative enzymes in duckweed (Lemna minor). Pestic Biochem Phys. 69(2):112-117.
Torrigiani P, Rabiti AL, Bortolotti C, Betti L, Marani F, Canova A, Bagni N (1997) Polyamine synthesis and accumulation in the hypersensitive response to TMV in Nicotiana tabacum. New Phytol. 135(3):467-473.

Walters DR (2003) Polyamines and plant disease. Phytochemistry. 64(1):97-107.

You X, Liu C, Liu F, Liu Y, Dong J (2012) Dissipation of pyraclostrobin and its metabolite BF-500-3 in maize under field conditions. Ecotox Environ safe. 80: 252-257.

Zapata PJ, Serrano M, García-Legaz MF, Pretel MT, Botella MA (2017) Short Term Effect of Salt Shock on Ethylene and Polyamines Depends on Plant Salt Sensitivity. Front Plant Sci. 8:1-13.

Zhan L, Hu J, Pang L, Li Y, Shao J (2014) Light exposure reduced browning enzyme activity and accumulated total phenols in cauliflower heads during cool storage. Postharvest Biol Tec. 88(95):17-20. 